\title{
EFEKTIFITAS PELATIHAN MANAJEMEN STRES PADA MAHASISWA
}

\author{
Gamma Rahmita Ureka Hakim \\ Fakultas Pendidikan Psikologi Universitas Negeri Malang, gamma.ike@gmail.com \\ Farah Farida Tantiani, \\ Fakultas Pendidikan Psikologi Universitas Negeri Malang, tantiani@yahoo.com \\ Pravissi Shanti \\ Fakultas Pendidikan Psikologi Universitas Negeri Malang, shanti.hakim@gmail.com
}

\begin{abstract}
Abstrak
Penelitian ini dilakukan untuk mengetahui efektivitas pelatihan manajemen stress. Hal ini merupakan tindakan pencegahan untuk meminimalkan efek negatif dari stres. Pengumpulan data dilakukan dengan menggunakan soal terkait materi yang disampaikan selama pelatihan. Penelitian ini bersifat quasi eksperimen berupa one group pre test, post test design. Pelatihan dilakukan selama dua hari dengan subyek penelitian sebanyak 80 mahasiswa yang berasal dari berbagai fakultas di Universitas Negeri Malang. Mereka diukur saat pre test, di beri perlakuan kemudian diberi post test. Materi yang diberikan dalam pelatihan ini adalah 1) Definisi Stress dan faktor penyebab; (2) Gejala-gejala Stress dan pengaruh stress dalam kehidupan sehari-hari; dan (3) Coping stress (4) simulasi dengan melakukan role play dan teknik relaksasi Setelah seluruh proses dilakukan, dilakukan post test dan dihitung perbedaan nilai meannya. Analisis dilakukan dengan paired sample t-test dengan nilai signifikansi 0,000 <alpha $(0,05)$. Hasil penelitian ini menunjukkan bahwa pelatihan manajemen stress ini tergolong efektif bagi mahasiswa. Mereka dapat memahami materi yang disampaikan dan dapat mempraktekkannya secara mandiri. Berdasarkan hasil pelatihan ini, disarankan untuk melakukan pelatihan dalam jangka waktu yang lebih lama dan berkelanjutan agar peserta lebih terampil untuk menjalankan strategi-strategi coping stress.
\end{abstract}

\section{Kata kunci : pelatihan management stress, mahasiswa}

\begin{abstract}
This study was conducted to determine the effectiveness of stress management training as a preventive effort to minimize the negative effects of stress. This research is quasi experiment in the form of one group pre test, post test design. Training conducted for two days with 80 students from various faculties at the State University of Malang. They were measured during pre test, given treatment and then given a post test. The material given in this training is 1) Definition of Stress and causal factors; (2) Symptoms of Stress and the effects of stress in everyday life; and (3) Coping stress (4) The simulation by performing role play and relaxation techniques. After the whole process is done, the difference of mean value between pre and post-test is calculated. The analysis was done by paired sample t-test with significance value 0,000 <alpha $(0,05)$. The results of this study indicate that stress management training is classified as effective for students. They can understand the material delivered and in the future can practice it independently. Based on the results of this training, it is advisable to conduct training in a longer period of time and continuously so that participants are more skilled to run coping stress strategies.

Keywords: stress management training, students
\end{abstract}


Setiap individu memiliki tuntutan dalam kehidupan baik secara pribadi dan sosial. Mahasiswa, sebagai salah satu generasi muda memiliki cukup banyak tekanan dalam hidup yang dapat memicu stres. Tekanan tersebut dapat berasal dari diri sendiri, keluarga, pendidikan, teman, dan lingkungan sosial lainnya. Secara akademik mahasiswa dituntut mendapatkan pemahaman yang mendalam dan komprehensif terkait bidang keilmuanannya. Ia juga memiliki tugas perkembangan untuk melakukan interaksi sosial dengan orang lain. Banyaknya tuntutan untuk menjalankan tugas perkembangan tersebut membuatnya harus berusaha dan berjuang dengan keras. Kondisi tersebut akan membuat mahasiswa menjadi individu yang tertekan. Kondisi yang menekan tersebut dapat menimbulkan stres.

Stres merupakan suatu kondisi yang tidak seimbang antara sumber pribadi (personal resources) dengan tuntutan yang dimiliki (Taylor, 1995). Ketidak seimbangan tersebut dipahami oleh individu sebagai hal yang berbahaya yang dapat mengancam keberadaannya. Markam (2003) menganggap stres merupakan keadaan ketika beban yang dirasakannyaterlalu berat dan tidak sepadan dengan kemampuan yang dimiliki untuk mengatasi beban yang dialaminya.

Banyaknya beban yang dirasakan oleh mahasiswa itulah yang membuat banyaknya fenomena yang muncul terkait dengan dampak dari stres pada mahasiswa. Banyak mahasiswa yang bunuh diri dikarenakan ketidakmampuan dalam menghadapi tekanan hidup.berdasarkan data yang dihimpun Mabes POLRI dari Kepolisian Daerah, Jawa Timur merupakan propinsi kedua tertinggi terkait kasus bunuh diri dengan 84 kasus( Linggasari, 2015). Oleh karena itu diperlukan langkah-langkah pencegahan untuk meminimalkan dampak negatif yang mungkin akan terjadi di masa depan. Mahasiswa perlu untuk melatih kemampuan untuk mengelola stres dengan cara yang positif sehingga dapat melaksanakan tugas-tugas pembangunan secara maksimal.

\section{MANAJEMEN STRES}

Schafer (2000) mengemukakan manajemen stress sebagai suatu kemampuan individu untuk mengelola stres yang timbul dalam kehidupan sehari-hari. Menurut Meichenbaum dan Jaremko (dalam Taylor, 1995) ada tiga tahap dalam program manejemen stres yaitu:
1. Tahap pertama, partisipan manajemen stres belajar mengenal stres dan bagaimana mengenali sumber stres yang muncul dalam kehidupannya.

2. Tahap kedua, partisipan mendapatkan dan mempraktekkan keterampilan coping terhadap stres.

3. Tahap ketiga, partisipan mempraktekkan teknik manajemen stres pada suatu peristiwa dan dilihat keefektifannya.

\section{METODE}

Penelitian ini merupakan penelitian ekperimen, dengan menggunakan variabel bebas berupa pelatihan manajemen stres, variabel tergantung berupa stres. Pada rancangan ini dilakukan pengukuran sebelum (pretest) dan pengukuran sesudah (posttest) pemberian perlakuan pada satu kelompok penelitian. Pretest dan posttest merupakan tes yang hasilnya bisa diperbandingkan. Berikut penjelasan desain eksperimen one-group pretest-posttest design dalam penelitian ini:

\section{$\mathrm{O}_{1} \rightarrow \mathrm{X}[\text { project }]_{1} \mathrm{X}[\text { project }]_{2} \mathrm{X}[\text { project }]_{3} \rightarrow$} $\mathrm{O}_{2}$

\section{Keterangan:}

$\mathrm{O}_{1} \quad$ : Pengukuran pretest

$\mathrm{O}_{2} \quad$ : Pengukuran posttest

X1 : Project 1: Pengenalan stres dan bagaimana mengenali sumber stres yang muncul dalam kehidupannya

$\mathrm{X} 2$ : Project 2 : Coping stres

X3 : Project 3: Simulasi teknik manajemen stress melalui role play dan teknik relaksasi

Subyek dalam penelitian ini adalah mahasiswa aktif Universitas Negeri Malang dengan jenjang S1 berusia 18-23 tahun. Teknik sampling yang dilakukan adalah random sampling terhadap 8 fakultas yang ada di Universitas Negeri Malang dengan jumlah 80 orang mahasiswa sebagai subyek penelitian.

\section{Instrument Penelitian}

Instrument penelitian adalah alat atau fasilitas yang digunakan oleh peneliti dalam mengumpulkan data agar pekerjaannya lebih mudah dan hasilnya lebih baik, dalam arti lebih cermat, lengkap, dan sistematis sehingga lebih mudah diolah (Arikunto, 2010). Beberapa instrument yangdigunakan dalam penelitian ini adalah : soal materi pelatihan untuk 
pretest dan posttest, kertas kerja untuk role play, music instrument untuk relaksasi.

1. Soal materi pelatihan: berisi pertanyaanpertanyaan seputar materi yang disampaikan oleh fasilitator untuk mengetahui sejauha mana pemahaman peserta tentang definisi dan faktor penyebab stress, gejala dan pengaruh stress dalam kehidupan sehari-hari, coping stress, teknik-teknik mengatasi stress melalui penentuan skala prioritas dan teknik relaksasi.

2. Kertas kerja untuk role play: merupakan kertas yang berisi peristiwa-peristiwa yang relevan yang terjadi pada mahasiswa dan mahasiswa ditugaskan untuk menyusun skala prioritas dalam penyelesaian masalah tersebut dengan menjabarkan langkah-langkah strategis.
3. Music instrument: digunakan untuk pengantar dalam melakukan relaksasi.

\section{Tahap Perlakuan}

Kegiatan pelatihan diselenggarakan dalam dua (2) hari, yaitu tanggal 3 dan 4 November 2016, dengan durasi waktu enam (6) jam pada setiap harinya. Pada hari pertama,diawali dengan seremonial pembukaan, dilanjutkan dengan penyampaian materi teoritis, meliputi: (1) Definisi Stress, faktor penyebab; (2) Gejala-gejala Stress dan pengaruh stress dalam kehidupan sehari-hari; dan (3) Coping stress. Pada hari kedua peserta diajak berlatih dengan menggunakan metode simulasi. Keterampilan yang dilatihkan melalui simulasi meliputi penentuan skala prioritas dan menurunkan stress dengan relaksasi. Kegiatan hari kedua diakhiri dengan evaluasi dan seremonial penutupan.

Berikut adalah tabel kegiatan pelatihan manajemen stress:

\begin{tabular}{|c|c|c|c|}
\hline NO. & TOPIK MATERI & PEMATERI & KETERANGAN \\
\hline \multicolumn{4}{|c|}{ Hari Pertama } \\
\hline 1. & $\begin{array}{l}\text { Pembukaan dan } \\
\text { pretest }\end{array}$ & $\begin{array}{l}\text { Penanggung jawab pelatihan } \\
\text { (Peneliti) }\end{array}$ & $\begin{array}{l}\text { Penyampaian tujuan pelatihan, batasan } \\
\text { yang akan dilakukan dalam pelatihan, } \\
\text { pretest }\end{array}$ \\
\hline 2. & $\begin{array}{l}\text { Definisi Stress, } \\
\text { faktor penyebab } \\
(2 \text { jam) }\end{array}$ & Konselor & $\begin{array}{l}\text { Penyampaian materi dilaksanakan } \\
\text { dengan metode ekspositori, divariasi } \\
\text { dengan tanya jawab, menggunakan } \\
\text { media power point. }\end{array}$ \\
\hline 3. & $\begin{array}{l}\text { Gejala-gejala Stress } \\
\text { dan pengaruh stress } \\
\text { dalam kehidupan } \\
\text { sehari-hari } \\
(2 \text { jam })\end{array}$ & Konselor & $\begin{array}{l}\text { Penyampaian materi dilaksanakan } \\
\text { dengan metode ekspositori, divariasi } \\
\text { dengan tanya jawab, menggunakan } \\
\text { media power point. }\end{array}$ \\
\hline 4. & $\begin{array}{l}\text { Coping stress } \\
(2 \text { jam })\end{array}$ & Konselor & $\begin{array}{l}\text { Penyampaian materi dilaksanakan } \\
\text { dengan metode ekspositori, divariasi } \\
\text { dengan tanya jawab, menggunakan } \\
\text { media power point. }\end{array}$ \\
\hline \multicolumn{4}{|c|}{ Hari kedua } \\
\hline 5. & $\begin{array}{l}\text { Role play } \\
\text { manajemen stress } \\
\text { melalui penentuan } \\
\text { skala prioritas } \\
(3 \text { jam) }\end{array}$ & Konselor, fasilitator training & $\begin{array}{l}\text { teknik simulasi bermain peran. } \\
\text { Dimana peserta dibagi menjadi } \\
\text { beberapa kelompok dan diminta } \\
\text { mendiskusikan skala prioritas bagi } \\
\text { mereka dan berlatih menyusun rencana } \\
\text { diri. }\end{array}$ \\
\hline 6. & $\begin{array}{l}\text { Menurunkan stres } \\
\text { dengan teknik } \\
\text { relaksasi } \\
(3 \text { jam })\end{array}$ & Psikolog & $\begin{array}{l}\text { Dalam latihan tersebut difasilitasi } \\
\text { dengan pemberian materi di awal } \\
\text { dalam bentuk ekspositori sebagai } \\
\text { pembekalan awal terkait teknik yang } \\
\text { diberikan kemudian dilanjutkan } \\
\text { dengan latihan relaksasi secara fisik } \\
\text { (relaksasi otot) dan kemudian relaksasi } \\
\text { meditasi }\end{array}$ \\
\hline 7. & Evaluasi & $\begin{array}{l}\text { Penanggung jawab Pelatihan } \\
\text { (Peneliti) }\end{array}$ & $\begin{array}{l}\text { Refleksi terhadap proses pelatihan, } \\
\text { posttest }\end{array}$ \\
\hline
\end{tabular}




\section{HASIL PENELITIAN}

\section{Deskripsi Data}

Proses pengambilan data dilakukan pada bulan November 2016. Jumlah subjek eksperimen dalam penelitian ini berjumlah 80 orang yang merupakan mahasiswa aktif Universitas Negeri Malang yang berasal dari 8 Fakultas yang ada. Penelitian ini menggunakan desain One-Group Pretest-Posttest Design.
Data hasil penelitian meliputi data pretest dan posttest efektivitas pelatihan manajemen stress mahasiswa. Data pretest merupakan data awal yang diperoleh sekaligus sebagai dasar pemberian perlakuan pertama. Data posttest merupakan data akhir yang diperoleh setalah diberikan perlakuan. Data yang diperoleh selanjutnya dikelompokkan dilakukan analisis dengan hasil sebagai berikut:

\section{Hasil analisa deskriptif manajemen stres pretest-post test}

\begin{tabular}{lllll}
\hline & Mean & Jumlah & Std. Deviation & Std. error mean \\
\hline Pretest & 9,61 & 80 & 2,808 & 0,314 \\
\hline Posttest & 13,80 & 80 & 2,383 & 0,266 \\
\hline
\end{tabular}

\section{Uji Hipotesa}

Hipotesa pada penelitian ini adalah ada perbedaan kemampuan manajemen stress antara sebelum dan sesudah pelatihan managemen stress. Penggunaan uji paired sampled t-test untuk menguji apakah hipotesa yang diajukan bisa diterima atau ditolak. Uji paired sampled t-test dilihat dengan membandingkan skor dari pretest dan posttest yang telah dilaksanakan, dan hasilnya dapat dilihat pada tabel di bawah ini:

Hasil uji paired sampled t-test pada kelompok penelitian dapat dilihat dari tabel 4.2

\begin{tabular}{llll}
\hline & $\mathrm{t}$ & $\mathrm{df}$ & Sig. (2-tailed) \\
\hline Pretest-posttest & $-12,746$ & 79 & 0,000 \\
\hline
\end{tabular}

Dari tabel di atas dapat dilihat nilai signifikasi $\mathrm{t}_{\text {hitung }}$ kurang dari 0.05 (sig. $<0.05$ ), maka dapat diketahui bahwa terdapat perbedaan yang

\section{PEMBAHASAN}

Berdasarkan hasil penelitian, dapat ditemukan bahwa terdapat perbedaan yang signifikan antara nilai pretest dan posttest. Hal tersebut menunjukkan bahwa pelatihan manajemen stress ini efektif bagi mahasiswa. Hampir semua peserta terlibat secara aktif dalam proses latihan. Hal ini didorong oleh skenario yang disiapkan yang memang memfasilitasi semua peserta untuk aktif berlatih. Dengan demikian kemampuan peserta dalam mengelola stress benar-benar terasah melalui signifikan antara mean skor pada pretest dan posttest manajemen stress.

proses pelatihan. Latihan dilaksanakan sesuai dengan skenario yang telah disiapkan sebelumnya oleh para nara sumber, yaitu penentuan skala prioritas dan teknik relaksasi.

Selama dua hari pelatihan penelitian, telah berhasil melatih 80 orang subyek. Materi yang dirancang, baik materi teoritis maupun materi keterampilan yang disampaikan melalui latihan dengan simulasi, dapat dilaksanakan sesuai dengan rancangan yang telah direncanakan. Materi yang dirancang dapat dilaksanakan secara tuntas. 
Namun, sebagian kecil peserta mengikuti kegaiatan dengan cara in-out. Dalam arti mereka masuk ke ruang pelatihan untuk mengikuti proses latihan, namun pada jam tertentu, mereka pamit untuk keluar ruangan, karena harus mengikuti perkuliahan pada mata kuliah tertentu, yang tidak berani mereka tinggalkan.

Secara umum peserta pelatihan menyatakan bahwa materi yang diperoleh bermanfaat bagi mereka, baik dalam kehidupan di lingkungan kampus maupun dalam kehidupan sosial seharihari. Sebagian peserta memberi masukan jika memungkinkan diadakan di setiap fakultas untuk mahasiswa agar masalah simulasi lebih terfokus. Dengan demikian mahasiswa mendapat bekal yang cukup dalam mengembangkan manajemen stress.

\section{A. KESIMPULAN DAN SARAN}

\section{Kesimpulan}

Kesimpulan yang diperoleh dari hasil penelitian ini adalah bahwa pelatihan ini efektif untuk memberikan keterampilan manajemen stress pada mahasiswa. Mereka dapat memahami materi yang disampaikan dan selanjutnya dapat mempraktekkannya secara mandiri.

Saran

Penelitian ini memberikan saran kepada beberapa pihak sesuai dengan hasil penelitian tersebut. Saran-saran tersebut adalah:

1. Untuk pihak kampus

Pelatihan manajemen stress ini diharapkan dapat dilakukan kembali dalam jangka waktu yang lebih lama dan berkelanjutan agar peserta lebih terampil untuk menjalankan strategi-strategi coping stress.

2. Untuk penelitian selanjutnya

Penelitian ini masih terbatas bentuk evaluasinya, yaitu hanya sebatas pengetahuan dan pemahaman peserta terkait materi yang disampaikan. Oleh karena itu diharapkan peneliti selanjutnya dapat melakukan evaluasi terkait perilaku peserta dan implementasi manajemen stress dalam kehidupan sehari-hari dengan mengembangkan alat ukur yang lebih komprehensif.

3. Bagi mahasiswa

Kepada mahasiswa disarankan untuk mengikuti pelatihan secara utuh agar lebih terampil dalam mengelola diri sehingga di masa mendatang dapat mempraktekkan secara berkelanjutan simulasi yang telah disampaikan dalam kehidupan mereka seharihari.

\section{DAFTAR PUSTAKA}

Arikunto, S. 2010. Prosedur Penelitian (Suatu Pendekatan Praktik). Jakarta: Rineka Cipta

Linggasari.Y. 2015. Menyoal Kasus Bunuh Diri di Indonesia.

https://www.cnnindonesia.com/nasional/201509 11165128-20-78152/menyoal-kasus-bunuh-diridi-indonesia/ (diunduh 8 Maret 2017)

Markam, S. 2003. Pengantar Psikologi Klinis. Jakarta: UI Press

Schafer, W. E. 2000. Stres Management for Wellness. California: Thompson Inc

Taylor, S.E. 1995. Health Psychology. Singapore: McGraw-Hill Book Co.

Kirkpatrick \&Kirkpatrick. 2007. Implementing the Fourlevels: A Practical Guide for Effective Evaluation of Training Program San Fransisco: Berrett-Koehler Publishers, Inc. 